Available online at GSC Online Press Directory

GSC Biological and Pharmaceutical Sciences

e-ISSN: 2581-3250, CODEN (USA): GBPSC2

Journal homepage: https://www.gsconlinepress.com/journals/gscbps

(RESEARCH ARTICLE)

\title{
Design and synthesis of novel 1-substituted -3-(4-oxo-2-phenylquinazolin-3(4H)-yl) urea and thiourea analogues targeting on TACE, as potent anticancer agents
}

\author{
Dhokale Sandhya ${ }^{1}$, Thakar Snehal ${ }^{1}$ and Bansode Deepali ${ }^{3, *}$ \\ ${ }^{1}$ Bharati Vidyapeeth (Deemed to be University), Poona College of Pharmacy, Kothrud, Pune-411038, Maharashtra, India. \\ 2 Department of Pharmaceutical Chemistry, Bharati Vidyapeeth (Deemed to be University), Poona College of Pharmacy, \\ Kothrud, Pune-411038, Maharashtra, India.
}

Publication history: Received on 01 August 2020; revised on 10 August 2020; accepted on 11 August 2020

Article DOI: https://doi.org/10.30574/gscbps.2020.12.2.0255

\begin{abstract}
1-substituted phenyl quinazolinones analogues were designed by performing molecular modelling studies against tumour necrosis factor alpha converting enzyme (TACE PDB Id: 2A8H) and in-silico Lipinski properties for drug likeness. From QSAR studies, it could be concluded that the urea and thiourea groups play a crucial role in enhancing cytotoxic effects of compounds. Substitution of halogens like trifluoromethyl, chloro and allylic functional group may enhance the cytotoxic effect of urea and thiourea analogues. Substitution of phenyl and benzoyl ring were not found effective against cancer. Also, the presence of substituted aromatic ring at position 3 and methyl or thiol group at position 2 are essential for antimicrobial activities of quinazolinone. The synthesized compounds were characterized by TLC, MP, IR, NMR and Mass spectral data and were screened for their anticancer activity. The in vitro anticancer studies were performed on six selected compounds using MTT assay against MDA MB-231 cell line using paclitaxel as a standard. The synthesized 1-substituted -3-(4-oxo-2-phenylquinazolin-3(4h)-yl) urea and thiourea derivatives exhibited significant anticancer activities.
\end{abstract}

\section{Graphical Abstract}<smiles>O=c1oc(-c2ccccc2)nc2ccccc12</smiles>

2-phenyl-4H benzo[d] [1,3]oxazin-4-one<smiles>NNc1c(N)ccc2c(=O)n(N)c(-c3ccccc3)nc12</smiles>

3-amino-2-phenyl quinazoline-4(3h)-one

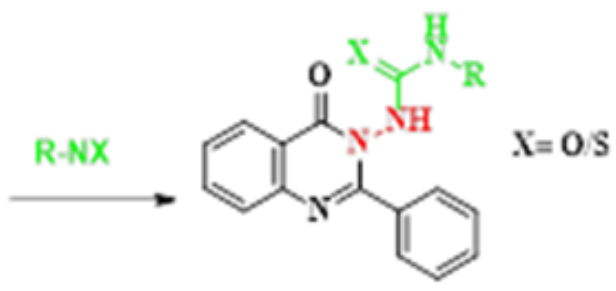

1-substituted-3-(4-0x0-2. phenylquinazolin-

$3(4 \mathrm{H})-\mathrm{yl})$ urea and thiourea analogues

Keywords: Anticancer; MDA-MB 231; MTT assay; Quinazolinone analogues; TACE

\section{Introduction}

In medicinal chemistry research heterocyclic compounds particularly $\mathrm{N}$-containing heterocyclic compounds are explored due to their wide scope of pharmacological activities [1]. The importance of heterocyclic compound in

\footnotetext{
${ }^{*}$ Corresponding author: Bansode Deepali

Bharati Vidyapeeth (Deemed to be University), Poona College of Pharmacy, Kothrud, Pune-411038, Maharashtra, India. 
medicinal chemistry is well established, most of the drugs available today contain heterocyclic scaffolds. In medicinal chemistry quinazolinone scaffold is one of the most important and privileged pharmacophores. A quinazolinone attracts the research over 100 years due to its unique features of the pharmacophore [2]. Quinazolinones have wide spectrum of their antibacterial, anticonvulsant, antifungal, anticancer, anti-HIV, anti-inflammatory, antitubercular and analgesic activities [3]. Quinazoline being a central pharmacophore, holds different substitutions at multiple sites. Modifications based around the fused ring of quinazolinone subsequently evaluate its usefulness in treating various disease conditions [4].

We have mainly focused on anticancer activity, because cancer is severe non-communicable disease Worldwide, which accounts for about 18.1 millions of new cases with 9.6 million of death each year, however India contributes about 1.2 million of cases every year. According to World Health Organization's recent reports, is second leading cause of death Worldwide [5]. There are over 100 types of cancer out of which lung, liver, colorectal, prostate, cervical, stomach and skin are more commonly observed. About 30\% of patients die due to late detection of cancer in past few years [6]. The current treatment of cancer includes chemotherapy, hormonal and surgical treatment, but it cannot hold the nerve of the disease due to late detection of cancer and painful chemotherapy. Cancer treatment can also develop carcinogenicity in patients [7]. To overcome such problems there is urgent need to develop new anticancer agents. Quinazolinone possess potent anticancer activity against various enzymes like TACE (Tumor Necrosis Factor $\alpha$ Converting Enzyme), EGFR (Epidermal Growth Factor Receptor), Tyrosine kinase, MMP (Matrix metallopeptidases), Aurora B kinase [8-11]. etc.

According to Mohan et. al. TACE is member of A disintegrin and metalloprotease (ADAM) family a key enzyme in cell cycle [12]. It belongs to multi-domain type I transmembrane protein that includes extracellular zinc dependent protease domain. Previously the enzyme was targeted for anti-inflammatory activity [13]. Gawad et. al. has synthesized some new substituted quinazolin- $4[3 \mathrm{H}]$ - ones and 3,4- dihydroquinazolin- $2[1 \mathrm{H}]$ analogues which exhibit potent anticancer activity against numerous cell lines that belong to various different tumor subpanels [14]. Ahemad et.al. (2013) has synthesized a three-novel series of 6,8- Dibromo-4 $(3 \mathrm{H})$ quinazolinone derivatives which have showed promising anticancer activity at very low concentrations against MCF-7 cell line using doxorubicin as control standard [15]. Noolvi et. al. has studied Qualitative structure activity realationship (QSAR) of synthesized substituted quinazoline and quinoxaline analogue. These novel analogues substituted with series of 2-Furano-4 (3H) quinazolinone were further screened for their anticancer potential and few analogues have shown good anticancer potential.

QSAR techniques enabled understanding the pharmacophoric requirement for quinazoline and quinoxaline derivatives. The overall outcome of the study revealed that the quinazoline ring is satisfactory backbone for antitumor activity [16]. Cao et.al. has synthesized a series of $4(3 \mathrm{H})$-quinazolinone derivatives with dithiocarbamate side chains which were synthesized and tested for their in vitro antitumor activity against human myelogenous leukemia K562 cells. Among them, (3,4-dihydro-2-methyl-4-oxoquinazolin-6-yl)- methyl 4-(4 fluorophenyl) piperazine-1-carbodithioate exhibited significant inhibitory activity against K562 cells with IC50 value of 0.51 M [17]. Xia et.al synthesized a series of 20, 30, 40, 6, 7-substituted 2-aryl quinazolinones and were screened for anticancer activity. Amongst them 17 compounds displayed significant growth inhibitory action against a panel of tumor cell lines. Dimethoxy substituted 2-aryl quinazolinone exhibited was found to be potent inhibitor of tubulin polymerization.

Compounds with flouro substitution displayed selective activity against P-gp-expressing epidermoid carcinoma of the nasopharynx [18]. Unnissa et. al. synthesized a series of disubstituted quinazolin 4(3H)-one derivatives which exhibited significant antitumour activity [19]. Saeedi. et.al. synthesized a novel series of quinazolinone-1,2,3-triazole hybrids which were evaluated for their in vitro $\alpha$-glucosidase inhibitory activity leading to efficient anti-diabetic agents [20]. On the basis of literature and drug design tool, we designed 1-substituted-3-(4-oxo-2-phenylquinazolin-3(4h)-yl) urea and thiourea analogues.

\section{Material and methods}

All chemicals were purchased from Sigma Aldrich Merck and were of synthetic grade. Reaction procedures were optimized on Radley's six station parallel combinatorial synthesizers and monitored on pre-coated aluminum plates (Merck silica gel 60F-254) using UV visualization technique and iodine vapors. All chemicals, reagents and solvents All the chemicals used were of synthetic grade. Pre-distilled solvents were used for reaction, characterization and purification. Melting points (uncorrected) were determined on programmable melting point and boiling point apparatus (VEEGO, India). IR spectra were recorded on JASCO V-530 FTIR 4100 .1H NMR was recorded on "Bruker Avance" Spectrometer at 100, 300, $400 \mathrm{MHz}$ frequency in CDCl3 and DMSO in presence of TMS as internal standard (Chemical shift in ppm). Mass spectra were obtained from G6460A triple quadrupole/MS/MS system (Agilent technologies) equipped with electrospray ionization technique. 
The In- silico drug properties calculation was performed using OSIRIS Data warrior (version 5.0.0.) which is based on Lipinski rule of five. In-vitro anticancer evaluation was carried out against MDA-MB 231 cell line at KLE University, Belgaum, Karnataka India.

\subsection{Designing of target molecules (SS, SS-A, SS-B, SS-01, SS-02, SS-03, SS-04)}

Designing of target molecules of quinazolinone was done by taking into consideration of two potent anticancer agents Gefitinib and Sorafenib which is given in (Figure. 1).

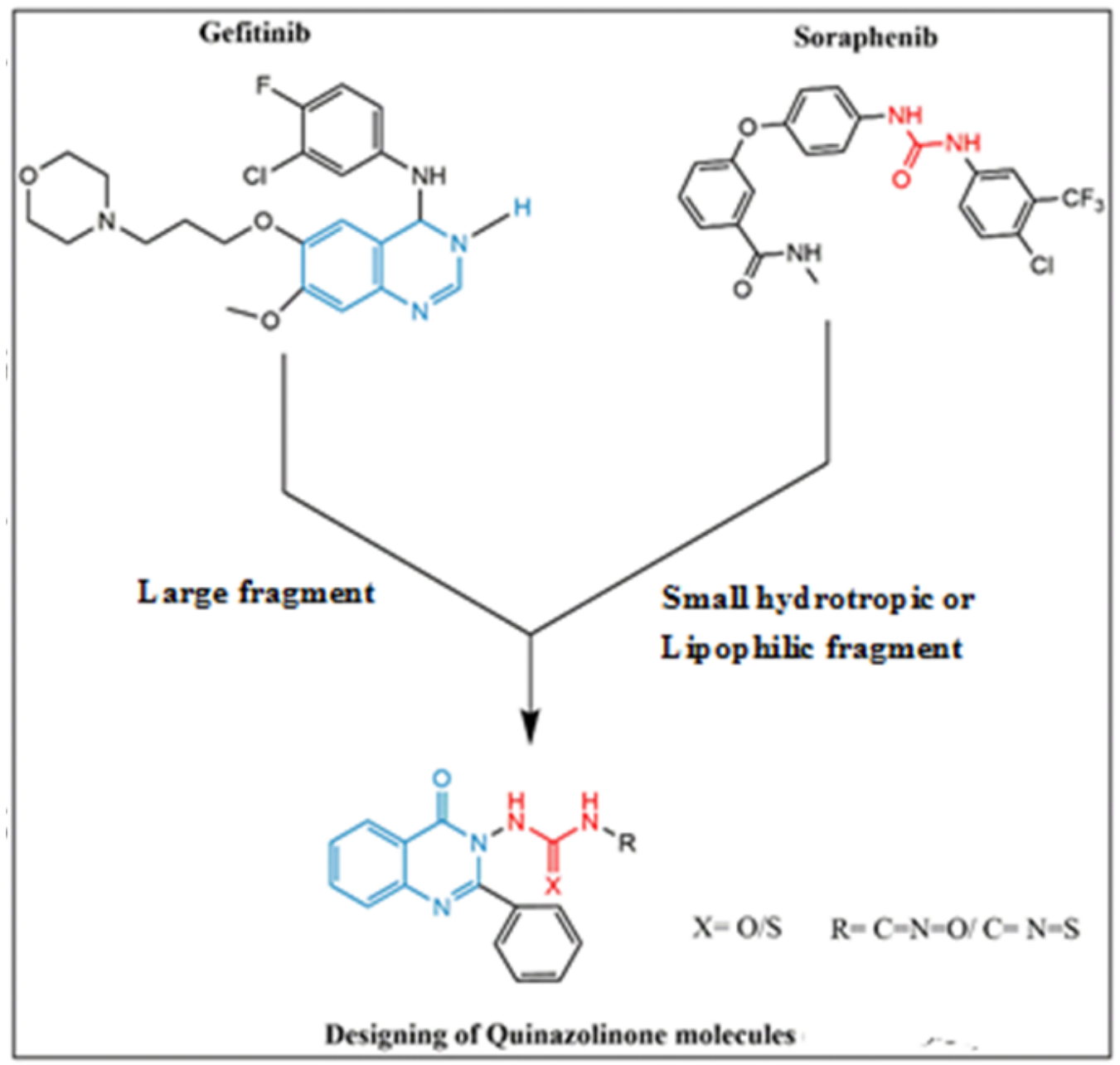

Figure 1 Designing of quinazolinone molecules

(In Figure 1. The quinazoline group from gefitinib which shown in blue color and the 4 Chloro-3- trifluoromethyl urea moiety shown in red color, were combined and modified to generate new molecules of quinazolinone)

\subsection{Synthesis of analogues (SS, SS-A, SS-B, SS-01, SS-02, SS-03, SS-04)}

On the basis of literature survey and structural activity relationship, six quinazolinone analogues were synthesized [2124]. i. e. SS, SS-A, SS-B, SS-01, SS-02, SS-03, SS-04 as depicted in (Table 1). 
Table 1 Synthesized 1-substituted-3-(4-oxo-2-phenylquinazolin-3(4H)-yl) urea and thiourea analogues

\begin{tabular}{|c|c|c|c|}
\hline $\begin{array}{l}\text { Sr. } \\
\text { No. }\end{array}$ & $\begin{array}{l}\text { Compound } \\
\text { Code }\end{array}$ & Structure & IUPAC Name \\
\hline 1 & SS & o & 2-amino benzoic acid \\
\hline 2 & SS-A & & 2-phenyl-4H benzo[d][1,3]oxazin-4-one \\
\hline 3 & SS-B & & $\begin{array}{l}\text { 3-amino-2-phenyl quinazoline-4(3h)-one- 4- } \\
\text { one }\end{array}$ \\
\hline 4 & SS-01 & & $\begin{array}{l}\text { 1-(4-oxo-2-phenylquinazolin-3(4H)-yl)-3- } \\
\text { phenylurea }\end{array}$ \\
\hline 5 & SS-02 & & $\begin{array}{l}\text { 1-(4-chloro-3-(trifluoromethyl)phenyl)-3-(4- } \\
\text { oxo-2-phenylquinazolin-3(4H)-yl)urea }\end{array}$ \\
\hline 6 & SS-03 & & $\begin{array}{l}\text { 1-benzyl-3-(4-oxo-2-phenylquinazolin-3(4H)- } \\
\text { yl) thiourea }\end{array}$ \\
\hline 7 & SS-04 & & $\begin{array}{l}\text { 1-(but-3-en-1-yl)-3-(4-oxo-2- } \\
\text { phenylquinazolin-3(4H)-yl) thiourea }\end{array}$ \\
\hline
\end{tabular}

\subsubsection{Synthesis of 2 aminobenzene carboxylic acid (SS)}

In a $350 \mathrm{ml}$ conical flask a solution of $4.0 \mathrm{~g}(0.1 \mathrm{~mol})$ of sodium hydroxide in $40 \mathrm{ml}$ of water was prepared and cooled. To this flask $26.2 \mathrm{~g}(8.4 \mathrm{ml}, 0.16 \mathrm{~mol})$ of bromine was added by shaking vigorously till bromine gets reacted. The temperature was set at $0{ }^{\circ} \mathrm{C} .2 \mathrm{~g}(0.05 \mathrm{~mol})$ of sodium hydroxide was dissolved in $20 \mathrm{ml}$ of water and $4 \mathrm{~g} \mathrm{(0.16 \textrm {mol } )}$ finely powered phthalimide was added into one portion in to the cold solution of sodium hypobromite. Sodium 
hydroxide solution was rapidly heated up to $80^{\circ} \mathrm{C}$ for about $2 \mathrm{~min}$, concentrated hydrochloric acid was slowly added to neutralize the solution. Anthranilic acid was precipitated completely by gradual addition of glacial acetic acid (20-25 $\mathrm{ml}$ ). The precipitate was filtered at vacuum pump and was recrystallized from hot water with addition of little decolorizing carbon (Scheme 1).<smiles>O=C1NC(=O)c2ccccc21</smiles>

Pthalimide

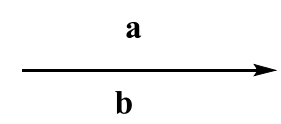<smiles>Nc1ccccc1C(=O)O</smiles>

Anthranilic acid

$$
\begin{aligned}
& \text { a: } \mathrm{NaOH}, \mathrm{Br}_{2} \\
& \text { b: } \mathrm{HCl}, \mathrm{CH}_{3} \mathrm{COOH}
\end{aligned}
$$

Scheme 1 Scheme for synthesis of Anthranilic acid

\subsubsection{Synthesis of 2-phenyl-4H benzo[d] [1,3] oxazin-4-one (SS-A)}

Anthranilic acid solution was prepared by adding $6.85 \mathrm{~g}(0.05 \mathrm{~mol})$ of anthranilic acid to 60 ml of pyridine. To this mixture $5.67 \mathrm{ml}(0.05 \mathrm{~mol})$ of benzoyl chloride was added drop wise at $0-2^{\circ} \mathrm{C}$ for 2 hours. Reaction mixture was stirred for 2 hours. The reaction mixture was neutralized with saturated sodium bicarbonate solution and solid product was filtered and re-crystallized from ethanol (Scheme 2).<smiles>Nc1ccccc1C(=O)O</smiles>

Anthranilic acid
Benzoyl chloride

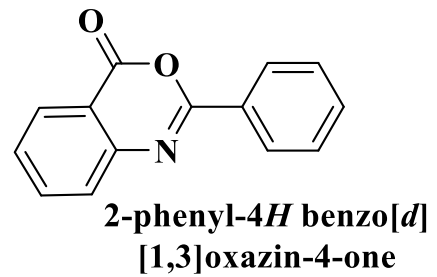

\section{a: Pyridine}

Scheme 2 Scheme for synthesis of 2-phenyl-4H benzo[d][1,3]oxazin-4s-one (SS-A)

\subsubsection{Synthesis of 3-amino-2-phenyl quinazoline-4(3h)-one- 4-one (SS-B)}

$2.2 \mathrm{~g}(0.01 \mathrm{~mol})$ of $4 \mathrm{H}$-benzo[d] [1, 3] Oxazin-4-one was dissolved in ethanol and $0.5 \mathrm{ml}(0.01$ mol $)$ of hydrazine hydrate was added to it with catalytic amount of pyridine. Reaction mixture was refluxed for 1 hour and after cooling a crystalline product was filtered and re-crystallized from ethanol (Scheme 3).
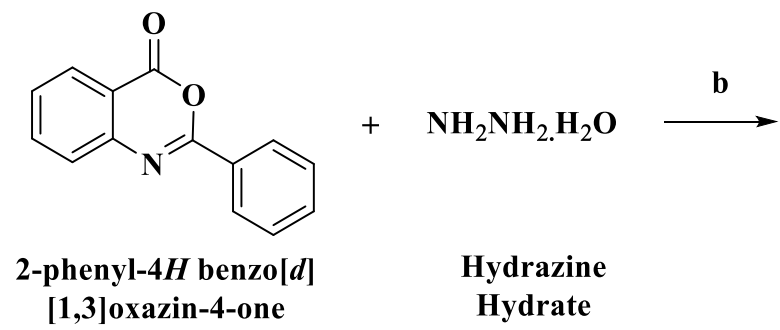
Hydrazine Hydrate<smiles>Nn1c(-c2ccccc2)nc2ccccc2c1=O</smiles>

3-amino-2-phenyl quinazoline-4(3h)-one

b: Ethanol, Pyridine

Scheme 3 Synthesis of 3-amino-2-phenyl quinazoline-4(3h)-one- 4-one (SS-B) 


\subsubsection{Synthesis of 1-substituted-3-(4-oxo-2-phenylquinazolin-3(4H)-yl) urea and thiourea analogues}

$2 \mathrm{~g}(0.0090 \mathrm{~mol})$ of 3-amino-4H-quinazolinone was dissolved in $10 \mathrm{ml}$ di-chloro methane (DCM). After stirring the reaction mixture for 5 minutes at room temperature $1.99 \mathrm{~g}(0.00900 \mathrm{~mol})$ of respective isocyanates were added in it and was stirred. After completion of reaction, product was filtered and re-crystallized from ethanol (Scheme 4).<smiles>[R]C([X])=[W]</smiles><smiles>[R]NC(=[X])Nn1c(-c2ccccc2)nc2ccccc2c1=O</smiles>

\section{1-substituted-3-(4-oxo-2-phenylquinazolin- $3(4 H)-y l)$ urea/thiourea derivatives}

Scheme 4 Scheme for synthesis of 1-substituted-3-(4-oxo-2-phenylquinazolin-3(4H)-yl) urea and thiourea analogues (SS-01 to SS-04)

\section{In silico drug properties}

The correlation of absorption, distribution, metabolism, excretion, toxicity and the prediction of physicochemical properties is necessary. For the prediction of physicochemical properties, OSIRIS Data warrior (version 5.0.0.) software was used which is based on Lipinski rule of five [25].

\section{Characterization of Synthetic analogues}

The synthesized analogues were characterized by thin layer chromatography, melting point, infrared spectroscopy, $1 \mathrm{H}$ NMR and mass spectrometric analysis [26].

\subsection{Biological Evaluation}

\subsubsection{Anticancer activity screening by Using MTT assay}

The anticancer activity of quinazolinone analogues was calculated through MTT viability assay. The effect of synthesized analogues on the viability of MDA-MB was analyzed by using MTT dye. $5 \times 10^{3}$ cells/well in a 96 -well flat-bottom micro plate was maintained at $37^{\circ} \mathrm{C}$ in $95 \%$ humidity and $5 \% \mathrm{CO}_{2}$ overnight. After 24 hours, the cells were incubated with fresh medium containing different concentrations $(1000,500,250,125,62.5,31.25 \mu \mathrm{g} / \mathrm{ml})$ of derivatives and the plates were further incubated for $24 \mathrm{hrs}$. The MTT solution $(5 \mathrm{mg} / \mathrm{ml})$ was added to each well, followed by 4 hours incubation at $37 \mathrm{uC}$ in $5 \% \mathrm{CO}_{2}$ incubator. The intensity of colored formazan derivative was determined by measuring optical density

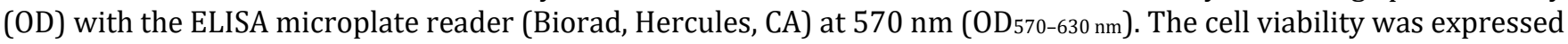
in terms of percentage. Percent surviving and incubating cells were calculated by the fallowing formula [27].

Surviving cells S $(\%)=\frac{\text { Mean OD of test compound }}{\text { Mean OD of negative control }} \mathrm{X} 100$

Inhibiting cells (\%) =100 - Surviving cells (S)

OD = Optical Density

\section{Results and discussion}

In this work, we have submitted the synthesized compounds against MDA- MB 231cell line for the analysis of Lipinski rule of five which indicates that whether a chemical compound could be orally active drug in humans. Our result showed that all the synthesized analogues fulfilled this rule. Less solubility of the synthesized compounds were predicted and was observed practically. The compounds were screened for anticancer activity on the basis of drug likeness score as shown in (Table 2). 
Table 2 OSIRIS calculation for Lipinski rule of five

\begin{tabular}{llllllll}
\hline Code & $\begin{array}{l}\text { Mol. } \\
\text { Weight }\end{array}$ & cLogP & cLogS & $\begin{array}{l}\text { H- } \\
\text { Acceptors }\end{array}$ & H-Donors & $\begin{array}{l}\text { Drug } \\
\text { likeness }\end{array}$ & Drug Score \\
\hline SS-A & 223.13 & 0.351 & -3.341 & 3 & 0 & 4.81418 & 0.571266 \\
SS-B & 237.13 & 0.8997 & -3.061 & 4 & 1 & 5.77379 & 0.598914 \\
SS-01 & 356.13 & 2.5345 & -4.389 & 5 & 1 & 0.2575 & 0.321117 \\
SS-02 & 458.08 & 3.9888 & -5.903 & 5 & 1 & 2.8979 & 0.716608 \\
SS-03 & 386.13 & 2.5326 & -4.354 & 5 & 1 & 0.35094 & 0.316608 \\
SS-04 & 350.12 & 2.1636 & -3.716 & 4 & 1 & 2.8868 & 0.716708 \\
\hline
\end{tabular}

The anticancer activity of 1- substituted - 3-(4-oxo-2-phenylquinazolin-3(4H)-yl) urea and thiourea analogues can be enhanced by making minor substitution. On the basis of literature survey and drug designing tool molecules can be further screened for anti-inflammatory, analgesic and anti-oxidant activity [28-30]. The results obtained following the synthetic procedures for the preparation of 1- substituted - 3-(4-oxo-2-phenylquinazolin-3(4H)-yl) urea and thiourea analogues are presented in (Table 3). Which depicts melting point, percentage yield, molecular formula, $\mathrm{R}_{f}$ of the synthesized analogues.

Table 3 Physical Constants of Synthesized compounds

\begin{tabular}{|c|c|c|c|c|c|}
\hline \multirow[t]{2}{*}{ Code } & \multirow[t]{2}{*}{ Structure } & \multicolumn{4}{|c|}{ Physical Constants } \\
\hline & & $\begin{array}{l}\text { Melting Point } \\
\left({ }^{\circ} \mathrm{C}\right)\end{array}$ & $\begin{array}{l}\text { Yield } \\
(\%)\end{array}$ & Mol. Formula & $R_{f}$ \\
\hline SS-A & & $118.0-120.8$ & 95 & $\mathrm{C}_{14} \mathrm{H}_{9} \mathrm{NO}_{2}$ & 0.85 \\
\hline SS-B & & $90.0-93.5$ & 92 & $\mathrm{C}_{14} \mathrm{H}_{11} \mathrm{~N}_{3} \mathrm{O}$ & 0.60 \\
\hline SS-01 & & $108.5-109.8$ & 90 & $\mathrm{C}_{21} \mathrm{H}_{16} \mathrm{~N}_{4} \mathrm{O}_{2}$ & 0.65 \\
\hline SS-02 & & $108.5-109.8$ & 95 & $\mathrm{C}_{22} \mathrm{H}_{17} \mathrm{~N}_{4} \mathrm{O}_{2}$ & 0.65 \\
\hline
\end{tabular}




\begin{tabular}{|c|c|c|c|c|}
\hline SS-03 & $208.5-210.7$ & 91 & $\mathrm{C}_{22} \mathrm{H}_{18} \mathrm{~N}_{4} \mathrm{OS}$ & 0.58 \\
\hline SS-04 & $101.5-103.8$ & 95 & $\mathrm{C}_{22} \mathrm{H}_{18} \mathrm{~N}_{4} \mathrm{OS}$ & 0.47 \\
\hline
\end{tabular}

\subsection{In silico drug likeness}

In this work, we have submitted the synthesized compounds against MDA- MB 231cell line for the analysis of Lipinski rule of five which indicates that whether a chemical compound could be orally active drug in humans. Our result showed that all the synthesized analogues fulfilled this rule. Less solubility of the synthesized compounds were predicted and was observed practically. The compounds were screened for anticancer activity on the basis of drug likeness score as shown in above table (Table 2).

The results obtained following the synthetic procedures for the preparation of 1- substituted - 3-(4-oxo-2phenylquinazolin-3(4H)-yl) urea and thiourea analogues are presented in Table 3. Which depicts melting point, percentage yield, molecular formula, $\mathrm{R}_{f}$ of the synthesized analogues.

\subsection{Spectroscopic characterization of synthesized analogues}

(SS) 2-Aminobenzenecarboxylic acid: IR vmax $\left(\mathrm{cm}^{-1}\right)(\mathrm{KBr}): 3324.17$ (NH str, $2^{0}$ amine), 3239.16 (=CH, str, aromatic), 2939.16 (-OH, Str, carboxylic acid),1719.06 (C=O, str carboxylic acid),1400.08 (C=C, ben aromatic); ${ }^{1} \mathrm{H}$ NMR (100 MHz in DMSO) $\delta 11.11(\mathrm{~s},-\mathrm{OH}, 1 \mathrm{H}), 6.74\left(\mathrm{~d},-\mathrm{NH}_{2}, 2 \mathrm{H}\right), 6.96-7.84(\mathrm{~m},-\mathrm{Ar}, 4 \mathrm{H})$; Mass (ESI): $\mathrm{m} / \mathrm{z}$ [M+ H]+ 137.16.

(SS-A) 2-phenyl-4H benzo[d][1,3] oxazin-4-one: IR vmax $\left(\mathrm{cm}^{-1}\right)(\mathrm{KBr}): 3034.44$ (C=C, str, aromatic), 1764.55 (C=N, str $2^{0}$ amine), 1617.02 (=CH, str aromatic), 1256.4 (C-O -C, str); ${ }^{1} \mathrm{H}$ NMR (100 MHz in DMSO) $\delta$ 7.53-8.15 (m, $\left.-\mathrm{Ar}, 9 \mathrm{H}\right)$; Mass (ESI): $\mathrm{m} / \mathrm{z}[\mathrm{M}+\mathrm{H}]^{+} 223.19$.

(SS-B) 3-amino-2-phenylquinazolin-4(3H)-one: IR vmax $\left(\mathrm{cm}^{-1}\right)(\mathrm{KBr}): 3355.53\left(\mathrm{~N}-\mathrm{NH}_{2}\right.$, str $1^{0}$ amine), 3306.36(C=NH, str $2^{0}$ amine), 3034.44 (C=C, str, aromatic), 1617.02 (=CH, str aromatic); ${ }^{1} \mathrm{H}$ NMR (100 MHz in DMSO) $\delta$ 7.53-8.15 (m, $-\mathrm{Ar}$, 9H, s, -NH, 2H); Mass (ESI): m/z [M+ H]+ 237.19.

(SS-01) 1-(4-oxo-2-phenylquinazolin-3(4H)-yl)-3-phenyl urea: IR vmax $\left(\mathrm{cm}^{-1}\right)(\mathrm{KBr}): 3286.11,\left(-\mathrm{NH}_{2}\right.$, str $1^{0}$ amine), 3032.51 ( $\mathrm{C}=0$, str carboxylic acid), 1674.88 ( $\mathrm{C}=0$, str amide), 1572.66 ( $\mathrm{C}=\mathrm{C}$, str aromatic), 1504.2 (=Ch, str aromatic); ${ }^{1} \mathrm{H}$ NMR (100 MHz in DMSO) $\delta 8.5380$ (s, 1H, NH), 8.559 (s, 1H, NH), 6.9543-7.9363 (m 14H, -Ar); Mass (ESI): m/z [M+ $\mathrm{H}]^{+} 356.29$.

(SS-02) 1-(4-chloro-3-(trifluoromethyl)phenyl)-3-(4-oxo-2-phenylquinazolin-3(4H)-yl) urea: IR vmax ( $\left.\mathrm{cm}^{-1}\right)(\mathrm{KBr})$ : $3340\left(-\mathrm{NH}_{2}\right.$, str $1^{0}$ amine), 1654(C=0, str amide), 1572.66 (C=C, str aromatic), 1504.2 (=Ch, str aromatic); ${ }^{1} \mathrm{H}$ NMR (100 $\mathrm{MHz}_{\mathrm{z}}$ in DMSO) $\delta 11.86(\mathrm{~s}, 1 \mathrm{H}), 9.39$ (s, 1H), 7.522-8.670 (m, 12H); Mass (ESI): m/z [M+ H]+ 458.49.

(SS-03) 1-benzyl-3-(4-oxo-2-phenylquinazolin-3(4H)-yl) thiourea: IR vmax ( $\left.\mathrm{cm}^{-1}\right)(\mathrm{KBr}): 3204.15\left(-\mathrm{NH}_{2}\right.$, str $1^{0}$ amine), 2933.2 (C=0, str amide), 1660.14 (C=C, str aromatic), 1504.2 (=Ch, str aromatic); ${ }^{1} \mathrm{H}$ NMR (100 MHz in DMSO) $\delta 11.960$ (s, 1H,-NH), $10.738(\mathrm{~s}, 1 \mathrm{H},-\mathrm{NH}), 4.721\left(\mathrm{t}, 2 \mathrm{H},-\mathrm{CH}_{2}-\right), 7.185-8.772(\mathrm{~m}, 14 \mathrm{H},-\mathrm{Ar}) ;$ Mass (ESI): m/z [M+ H] 386.14.

(SS-04) 1-(but-3-en-1-yl)-3-(4-oxo-2-phenylquinazolin-3(4H)-yl) thiourea: IR vmax ( $\left.\mathrm{cm}^{-1}\right)(\mathrm{KBr}): 3204.15\left(-\mathrm{NH}_{2}\right.$, str $1^{0}$ amine), 2933.2 (C=0, str amide), 2260.44 (C)1660.14 (C=C, str aromatic), 1504.2 (C=C, str aromatic); ${ }^{1} \mathrm{H}$ NMR (100MHz in DMSO) $\delta 11.960(\mathrm{~s}, 1 \mathrm{H},-\mathrm{NH}), 10.738(\mathrm{~s}, 1 \mathrm{H},-\mathrm{NH}), 3.95\left(\mathrm{t}, 2 \mathrm{H},-\mathrm{CH}_{2}-\right), 7.185-8.772(\mathrm{~m}, 9 \mathrm{H},-\mathrm{Ar})$; Mass (ESI): m/z [M+ $\mathrm{H}]^{+} 350.44$. 


\subsection{Anti-cancer activity}

The anticancer activity of synthesized compounds was carried out by using MTT [3-(4,5-dimethylthiazol-2-yl)-2,5diphenyltetrazoliumbromide] cyto-toxicity assay on MDA MB 231 (breast cancer cell line). The anticancer activity was recorded against paclitaxel. The cytotoxic effects are summarized in (Table 4). The observed data did not follow a doseresponse pattern, which implied no change in response to increasing doses as cell growth was not seen to be inhibited, due to which the $\mathrm{IC}_{50}$ value of the quinazolinone analogues was unable to determined. To compare the effects of individual analogues against basal, one -way (Analysis of Variance) ANOVA was used by using Graph Pad Prism v5 statistical analysis package (GraphPad Software Inc., La Jolla, CA). It was apparent that the effects of the analogues differ on cells showing that some drugs do inhibit the cell growth as shown in (Figure 2.) SS-02 showed a significant difference in cell viability at the lowest dose tested than basal and SS-04 showed significant difference at most of the tested concentrations as compared to basal.

Table 4 Anticancer activity of the synthesized compound on MDA-MB breast cancer cell line.

\begin{tabular}{lllllll}
\hline $\begin{array}{l}\text { Conc. } \\
(\boldsymbol{\mu g} / \mathbf{m l})\end{array}$ & \multicolumn{2}{l}{ \% Cell Viability (expressed as \% of basal) } & & & \\
& SS-A & SS-B & SS-01 & SS-02 & SS-03 & SS-04 \\
\hline 0 & 100 & 100 & 100 & 100 & 100 & 100 \\
31.25 & 92.3847 & 86.6859 & 83.6956 & 62.1376 & 75.8152 & 58.9673 \\
62.05 & 87.8711 & 74.6359 & 92.9347 & 68.2065 & 81.1594 & 67.4818 \\
125.00 & 100.0957 & 81.5194 & 86.5942 & 70.8333 & 74.3659 & 59.8731 \\
250.00 & 70.7101 & 67.8418 & 93.0253 & 79.5289 & 100.9057 & 70.4710 \\
500.00 & 79.2899 & 75.6852 & 87.6811 & 72.4637 & 73.7318 & 64.8550 \\
1000 & 73.2246 & 70.5310 & 86.8659 & 68.2065 & 73.8224 & 64.1304 \\
\hline
\end{tabular}
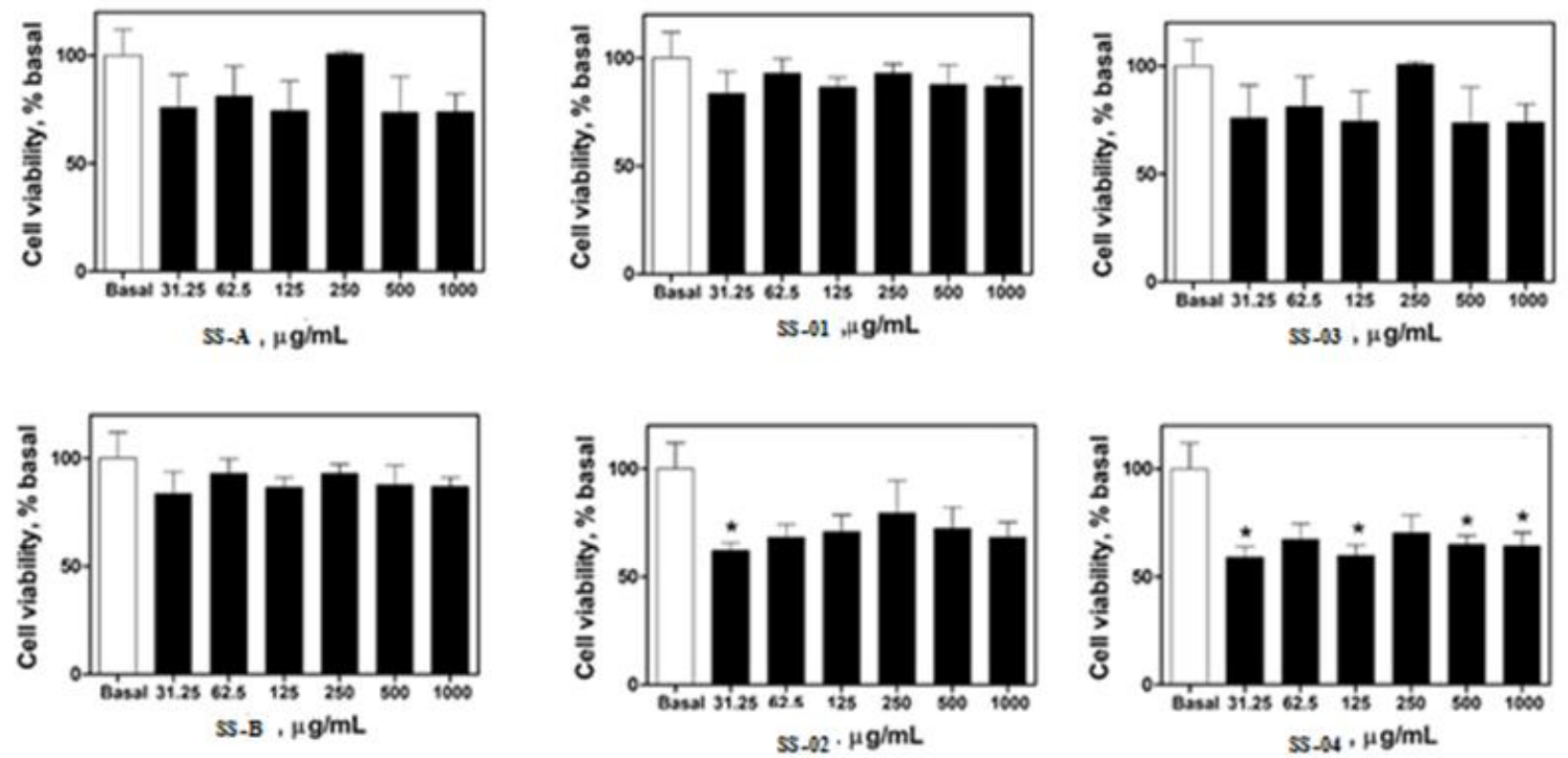

Figure 2 Basal graph of individual analogues

\section{Discussion}

The 1- substituted - 3-(4-oxo-2-phenylquinazolin-3(4H)-yl) urea and thiourea was obtained in the range of 90-95 \%. It indicates that the synthetic pathway used for synthesis is suitable for quinazolinone urea and thiourea analogues of this kind. The Lipinski's rule of five for prediction of drug likeness of new chemical entities. The existing quinazolinone 
compounds possesses exhibit greater bioavailability, solubility and potent anticancer activity. The anticancer activity of 1- substituted - 3-(4-oxo-2-phenylquinazolin-3(4H)-yl) urea and thiourea analogues can be enhanced by making minor substitution. The observed data did not follow a dose-response pattern, which implied no change in response to increasing doses as cell growth was not seen to be inhibited, due to which the $\mathrm{IC}_{50}$ value of the quinazolinone analogues was unable to determined. To compare the effects of individual analogues against basal, one -way ANOVA was used by using Graph Pad Prism v5 statistical analysis package (GraphPad Software Inc., La Jolla, CA). It was apparent that the effects of the analogues differ on cells showing that some drugs do inhibit the cell growth as shown in (Figure 2.) SS-02 showed a significant difference in cell viability at the lowest dose tested than basal and SS-04 showed significant difference at most of the tested concentrations as compared to basal. On the basis of literature survey and drug designing tool molecules can be further screened for anti-inflammatory, analgesic and anti-oxidant activity [28-29].

\section{Conclusion}

The current investigation of anticancer activity of synthesised 1-(4-oxo-2-phenylquinazolin-3(4H)-yl) urea and thiourea against MDA-MB 231 cancer cell line describes about the basic scaffold design required for anticancer analogues. The molecular modelling studies indicates the TACE can be more useful target for anticancer drug development. The results show that the current research work develops an efficient protocol for the synthesis of phenyl quinazolinone analogues, and the molecules can be further considered for development of potent anticancer agents.

\section{Compliance with ethical standards}

\section{Acknowledgments}

The authors are thankful to Principal, Poona College of Pharmacy, Pune for encouragement and support in carrying out the work. We would also like to thank Dr. Sanjay Mishra, Belgaum, India for providing facility to perform antiproliferative activity and Dr. Victor M. Pulgar, Associate Professor, Campbell University, USA, for his valuable guidance in statistical study of cell lines.

\section{Disclosure of conflict of interest}

The authors declare that there is no conflict of interests regarding the publication of this research article.

\section{References}

[1] Rakesh KP, Darshini N, Shubhavathi T and Mallesha N. (2017). Biological applications of quinazolinone analogues: A review. Org Med Chem, 2(2), 1-5.

[2] Kavitha K, Shrinivasan N and Haribabu Y. (2018) A review on quinazolinone and its derivatives with diverse biological activities. World J Pharm Pharm Sci, 7(4), 628-649.

[3] Amol SJ and Sunil VA. (2017). Substituted quinazoline a potential drug candidate: an overview. World J Pharm Res, 6(15), 281-295.

[4] El-Azab AS, Al-Omar MA, Alaa AM, Abdel-Aziz NI, Magda AA, Aleisa AM, Sayed-Ahmed MM and Abdel-Hamide SG. (2010). Design, synthesis and biological evaluation of novel quinazoline derivatives as potential antitumor agents: molecular docking study. Eur J Med Chem, 45(9), 4188-4198.

[5] World Health Organization. (2020).

[6] Bray F, Ferlay J, Soerjomataram I, Siegel RL, Torre LA and Jemal A. (2018). Global cancer statistics 2018: GLOBOCAN estimates of incidence and mortality worldwide for 36 cancers in 185 countries. CA Cancer J Clin, 68, 394-424.

[7] KD Tripathi. (2013). Essentials of Medical Pharmacology. New Delhi, India Jaypee brother's medical publishers (P) ltd.

[8] Nara H, Sato K, Naito T, Mototani H, Oki H, Yamamoto Y, Kuno H, Santou T, Kanzaki N, Terauchi J and Uchikawa 0. (2014). Discovery of novel, highly potent, and selective quinazoline-2-carboxamide-based matrix metalloproteinase (MMP)-13 inhibitors without a zinc binding group using a structure-based design approach. J Med Chem, 57(21), 8886-8902. 
[9] Barlési F, Tchouhadjian C, Doddoli C, Villani P, Greillier L, Kleisbauer JP, Thomas P and Astoul P. (2005). Gefitinib (ZD1839, Iressa ${ }^{\circledR}$ ) in non-small-cell lung cancer: a review of clinical trials from a daily practice perspective. Fundam Clin Pharmacol, 19(3) 385-393.

[10] Ballard P, Bradbury RH, Harris CS, Hennequin LF, Hickinson M, Kettle JG, Kendrew J, Klinowska T, Ogilvie DJ, Pearson SE and Williams EJ. (2005). Inhibitors of epidermal growth factor receptor tyrosine kinase: optimisation of potency and in vivo pharmacokinetics. Bio Med Chem Lett, 16(18), 4908-4912.

[11] Marzaro G, Guiotto A and Chilin A. (2012). Quinazoline derivatives as potential anticancer agents: a patent review (2007-2010). Expert Opin Ther Pat, 22(3), 223-252.

[12] Mohan MJ, Seaton T, Mitchell J, Howe A, Blackburn K, Burkhart W, et al. (2002) The tumor necrosis factor- $r$ converting enzyme (TACE): a unique metalloproteinase with highly defined substrate selectivity. Biochemistry, 41(30), 9462-69.

[13] Black RA. (2004). Tumor necrosis factor- a converting enzyme In. Handbook of Proteolytic Enzymes Aspartic and Metallo peptidase, 726- 729.

[14] Abdel Gawad NM, Georgey HH, Youssef RM and El-Sayed NA. (2010). Synthesis and antitumor activity of some 2, 3-disubstituted quinazolin-4(3H)-ones and 4, 6- disubstituted- 1, 2, 3, 4-tetrahydroquinazolin- 2H-ones. Eur J Med Chem, 45(12), 6058-6067.

[15] Ahmed MF and Youns M. (2013). Synthesis and biological evaluation of a novel series of 6, 8-dibromo-4(3H) quinazolinone derivatives as anticancer agents, Arch Pharm, 346(8), 610-617.

[16] Noolvi M, Patel H, Bhardwaj V and Chauhan A. (2011). Synthesis and in-vitro anti-tumor activity of substituted quinazoline and quinoxaline derivatives: Search for anticancer agent. Eur J Med Chem, 46(6), 2327-2346.

[17] Cao SL, Feng YP, Jiang YY, Liu SY, Ding GY and Li RT. (2005). Synthesis and in vitro antitumor activity of 4 (3H)quinazolinone derivatives with dithiocarbamate side chains. Bioorganic Med Chem Lett, 15(7), 1915-1917.

[18] Xia Y, Yang ZY, Hour MJ, Kuo SC, Xia P, Bastow KF, et al. (2011). Antitumor agents. Part 204: Synthesis and biological evaluation of substituted 2-aryl quinazolinones. Bioorganic Med Chem Lett, 11(9), 1193-1196.

[19] Hurmath Unnissa S, Reddy GK and Aravazhi T. (2013). Synthesis and in Vitro anti-tumor activity of some novel 2, 3-disubstituted quinazolin 4(3H)-one derivatives. J Appl Pharm Sci, 3(10), 136-140.

[20] Saeedi M, Mohammadi-Khanaposhtani M, Pourrabia P, Razzaghi N, Ghadimi R, Imanparast S, Faramarzi MA, Bandarian F, Esfahani EN, Safavi M and Rastegar H. (2019). Design and synthesis of novel quinazolinone-1, 2, 3triazole hybrids as new anti-diabetic agents: In vitro $\alpha$-glucosidase inhibition, kinetic, and docking study. Bioorganic chemistry, 83, 161-9.

[21] Dahiya R, Kumar A and Yadav R. (2008). Synthesis and Biological Activity of Peptide Derivatives of Iodoquinazolinones/Nitroimidazoles. Molecules, 13(3), 958-76.

[22] Rajveer CH and Kumaraswamy SR. (2010). Synthesis of some 6-bromo quinazolinone derivatives for their pharmacological activities. Int J Pharm Bio, 6(2), 50-56.

[23] Dhokale SR, Thakar SR, Bansode DA and Mahadik KR. (2019). Synthesis, screening of novel 1-substituted-3- (4oxo-2-phenylquinazolin- $3(4 \mathrm{H})$-yl) urea and thiourea analogues as potent antibacterials. Int J Pharm Pharm Sci, 11(11), 38-42.

[24] Furniss BS, Hannaford AJ, Smith PWG and Tatchell AR. (1998). Vogel's textbook of practical organic chemistry. United Kingdom, Pearson education Limited.

[25] Messali M, Aouad MR, Ali AA, Rezki N, Hadda TB and Hammouti B. (2015). Synthesis, characterization, and POM analysis of novel bioactive imidazolium-based ionic liquids. Med Chem Res, 24, 1387-1395.

[26] Pavia D, Lampmanh H and Kvizgeorge. (2017). Introduction to Spectroscopy, Boston UK, Cengage Learning.

[27] Wani KD, Kitture R, Ahmed A, Choudhari AS, Koppikar SJ, Kale SN and Kaul-Ghanekar R. (2011). Synthesis, characterization and in vitro study of curcumin-functionalized citric acid-capped magnetic (CCF) nanoparticles as drug delivery agents in cancer. J Bionano, 5(1), 59-65.

[28] Saravanan G, Alagarsamy V and Prakash CR. (2015). Synthesis, characterization and in vitro antimicrobial activity of some 1-(substitutedbenzylidene)-4-(4-(2-(methyl/phenyl)-4-oxoquinazolin-3 $\quad(4 \mathrm{H})-\mathrm{yl}) \quad$ phenyl) semicarbazide derivatives. J Saudi Chem Soc, 19(9), 3-11. 
GSC Biological and Pharmaceutical Sciences, 2020, 12(02), 194-205

[29] Eweas AF, El-Nezhawy AO, Baiuomy AR and Awad MM. (2012). Design, synthesis, anti-inflammatory, analgesic screening, and molecular docking of some novel 2-pyridyl (3H)-quinazolin-4-one derivatives. Med Chem Res, 22, 1011-20. 